\title{
COLORECTAL CARCINOMA: A SIX YEARS EXPERIENCE AT A TERTIARY CARE HOSPITAL OF SINDH
}

\author{
Khalid Ahsan Malik
}

\begin{abstract}
OBJECTIVE: To find out the frequency of colorectal carcinoma in our population. DESIGN: Case Series.

METHODS: All patients with colorectal carcinoma admitted in surgical department of People's Medical College Hospital, Nawabshah Sindh - Pakistan from September 1996 to September 2001 were included in the study.

RESULTS: Total fifty-six patients with age range of 14 to 70 years; thirty males and twenty six females were studied. Most of the patients were in fifth and sixth decades of their life. Only ten patients with colorectal carcinoma were in twenty-one to thirty years age group while two patients were below the age of twenty years. Common sites involved were rectum (46.43\%) followed by sigmoid colon (28.57\%). Bleeding per rectum $(62.05 \%)$ and altered bowel habits (35.71\%) were the commonest symptoms. Histo-pathologically, twenty patients had well differentiated adeno-carcinoma (35.72\%) where as eighteen patients had anaplastic tumour (32.14\%) and mucinous adeno-carcinoma was found in five patients (8.92\%).

CONCLUSION: Colorectal carcinoma is affecting even the younger age group in our set up. Bleeding per rectum and altered bowel habits are the main symptoms and these symptoms irrespective of the age should be thoroughly investigated.
\end{abstract}

KEY WORDS: Carcinoma. Rectum. Colon.

\section{INTRODUCTION}

Colorectal carcinoma is the third most common malignant tumour in the world ${ }^{1}$ and in United States, it is the second leading cause of cancer related deaths. ${ }^{2}$ The incidence is higher in men than women. In men, it ranges from 48.3 to 72.5 per 100,000 per year while in women, it ranges from 32.3 to 56 per 100,000 per year. ${ }^{3,4}$ About $6 \%$ of Americans are expected to develop the disease within their life time. ${ }^{3}$ Higher incidence of colorectal cancer is found in those with hereditary conditions such as familial adenomatous polyposis and hereditary nonpolyposis. Together, they account for no more than $6 \%$ of colorectal cancer cases. More common conditions associated with an increased risk include a personal history of colorectal cancer or adenomas, first degree relative with colorectal cancer, first degree relative with adenoma diagnosed before 60 years of age $\mathrm{e}^{5}$, personal history of breast, ovarian and endometrial cancer and personal history of long standing chronic ulcerative colitis or crohn's colitis. ${ }^{6-7}$ These high risk groups account for about a quarter of all colorectal cancers. Epidemiologi$\mathrm{cal}$, experimental and genetic ${ }^{8}$ studies suggest that colorectal cancer results from complex interaction between inherited susceptibility and environmental or life style factors. Measures which reduce the incidence and prevalence of adenomas may result in decrease in the risk of colorectal cancer. ${ }^{9}$ The formation and spontaneous regression of adenomas may also be a dynamic process ${ }^{10}$ in reducing colorectal cancer. The present study was conducted to find out the frequency of colorectal carcinoma in our set up.

\section{PATIENTS AND METHODS}

This study was conducted on fifty-six patients at the Department of Surgery, People's Medical College Hospital, Nawabshah Sindh - Pakistan from September 1996 to September 2001. The parameters examined were age, sex, presenting symptoms and signs, location of tumour, extent and spread and histopathology. Diagnostic modalities included digital rectal examination, procto-sigmoidoscopy, abdominal ultrasound, contrast studies, colonoscopy, computerized tomography and I/V urography in selected cases. All the patients with the diagnosis of colorectal cancer were included in the study.

\section{RESULTS}

Out of fifty-six patients suffering from colorectal carci- 
noma, thirty patients were males and twenty-six females. Age varied from fourteen years to seventy years (Table I). Male to female ratio did not show much difference. Commonest site involved was rectum (26\%) followed by sigmoid colon (16\%) (Table II). Bleeding per rectum was the commonest symptom (62.05\%) followed by altered bowel habits (35.71\%). Twelve patients $(21.43 \%)$ presented with intestinal obstruction (Table III). Primary resection of the growth was possible only in eight patients (14.29\%) and right hemicolectomy was performed in the same number of the patients (14.29\%). Anterior resection was done in eleven patients (19.19\%). Abdomino-perineal resection was possible in only ten patients (17.86\%) According to modified Duke's classification, twenty patients $(35.71 \%)$ were in grade B, eighteen (32.14\%) in grade $C$ and the same number of patients (32.14\%) in grade D. Histopathologically, twenty patients had well differentiated adeno-carcinoma (35.72\%) where as eighteen patients had anaplastic tumour (32.14\%) and mucinous adeno carcinoma was found in five patients (8.92\%) (Table IV).

TABLE I:

AGE DISTRIBUTION OF CASES

\begin{tabular}{|c|c|c|}
\hline Age Group & No. of Cases & Percentage \\
\hline $11-20$ Years & 02 & $(03.58 \%)$ \\
\hline $21-30$ Years & 10 & $(17.85 \%)$ \\
\hline $31-40$ Years & 07 & $(12.50 \%)$ \\
\hline $41-50$ Years & 06 & $(10.72 \%)$ \\
\hline $51-60$ Years & 17 & $(30.35 \%)$ \\
\hline $61-70$ Years & 14 & $(25.00 \%)$ \\
\hline Total & $\mathbf{5 6}$ & $\mathbf{( 1 0 0 \% )}$ \\
\hline
\end{tabular}

TABLE II:

SITE OF INVOLVEMENT

\begin{tabular}{|l|c|c|}
\hline \multicolumn{1}{|c|}{ Site } & No. of Cases & Percentage \\
\hline Anal canal & 03 & $(05.35 \%)$ \\
\hline Rectum & 26 & $(46.43 \%)$ \\
\hline Sigmoid & 16 & $(28.57 \%)$ \\
\hline Descending colon & 02 & $(03.57 \%)$ \\
\hline Transverse colon & 01 & $(01.79 \%)$ \\
\hline Ascending colon & 01 & $(01.79 \%)$ \\
\hline Caecum & 07 & $(12.50 \%)$ \\
\hline
\end{tabular}

TABLE III: SYMPTOMS IN CASES

\begin{tabular}{|l|c|c|}
\hline & $\begin{array}{c}\text { No. of } \\
\text { Cases }\end{array}$ & Percentage \\
\hline Altered bowel habits & 20 & $(35.71 \%)$ \\
\hline Bleeding per rectum & 35 & $(62.05 \%)$ \\
\hline Pain in abdomen & 28 & $(50.00 \%)$ \\
\hline Palpable abdominal mass & 14 & $(25.00 \%)$ \\
\hline Tenes mus & 10 & $(17.86 \%)$ \\
\hline Mucus discharge & 08 & $(14.29 \%)$ \\
\hline Intestinal obstruction & 12 & $(21.43 \%)$ \\
\hline
\end{tabular}

TABLE IV:

HISTOPATHOLOGY FINDINGS OF TUMOUR

\begin{tabular}{|l|c|c|}
\hline \multicolumn{1}{|c|}{ Type } & $\begin{array}{c}\text { No. of } \\
\text { Patients }\end{array}$ & $\%$ \\
\hline Well Differentiated & 20 & 35.72 \\
\hline Moderately differentiated & 08 & 14.29 \\
\hline Poorly differentiated & 05 & 08.93 \\
\hline Anaplastic & 18 & 32.14 \\
\hline Mucinous adeno Carcinoma & 05 & 08.92 \\
\hline
\end{tabular}

\section{DISCUSSION}

It was thought that people living in Asian subcontinent having predominant vegetarian dietary habits protect themselves from colorectal cancer ${ }^{13}$ but this does not hold true and studies show a substantial increase in the number of patients of colorectal cancer and particularly the incidence at younger age is almost the same as in high-risk patients of the West. ${ }^{12-14}$ Family history of familial polyposis coli, family cancer or history of inflammatory bowel disease were not found in this study which is an important factor for colorectal cancer in Western studies. ${ }^{15-16}$ Rectal bleeding and pain were the presenting symptoms in most of our patients of colorectal malignancy followed by the symptoms of recent changes in bowel habits. These findings are comparable with other studies. ${ }^{11,14,17,18}$ More than $50 \%$ cases of the carcinoma presented in rectum and sigmoid region in this study. Studies from different regions have documented almost similar figures regarding location of malignancy. ${ }^{11,13,14,19}$ Histopathology reports in most of our patients showed well and moderately differentiated tumour whereas O'Connell ${ }^{20}$ study has reported that more than $50 \%$ of pa- 
tients suffer moderately or poorly differentiated tumour.

\section{CONCLUSION}

Colorectal cancer at young age seems at rise in our set up. Rectal bleeding and altered bowel habits are the main symptoms and these irrespective of the age should be thoroughly investigated. As these cancers, if detected earlier, it is more likely that its treatment will be successful.

\section{REFERENCES}

1. Shike M, Winawer SJ, Greenwald PH. Primary prevention of colorectal cancer: the WHO collaborating center for the prevention of colorectal cancer. Bull World Health Org.1990; 68(3): 377-85.

2. Amrican Cancer Society. Cancer facts and figures 2006 Atlanta Ga. American Cancer Society 2006.

3. Ries LAG, Eisuer MP, Kosary CL, et al. Cancer statistics review 1975-2000, Bethesda Md. National Cancer Institute, USA. 2005.

4. Edward BK, Howe HL, Ries LA. Annual report to the nation on the studies of cancer 1973-1999 featuring implication of age and aging on U.S Cancer burden. Cancer. 2002; 94(10): 2766-92.

5. Ahsan H, Neugeut Al, Garbowski GC. Family history of colorectal adenomatous polyps and increased risk of colorectal cancer. Ann Intern Med. 1998;128(11)900-5.

6. Fuchs CS, Giovanucci EL, Colditz GA. A prospective study of family history and the risk of colorectal cancer. N Eng J Med. 1994; 331(25):1669-74.

7. Smith RA, Von Eschenbach AC, Wender. American cancer society guidelines for the early detection of cancer. Update of early detection guidelines for prostate, colorectal and endometrial cancer, also update 2001-testing for early lung cancer detection. Ca Cancer J. 2001; 51(1)38-75 quiz 77-80.

8. Fearon ER, Vogelstein B. A genetic model for coIorectal tumorigensis. Cell. 1990; 61(J)759-67.

9. Winawer SJ, Zauber AG, Homn. Prevention of colorectal cancer by colonoscopical polypectomy; The National Polyp Study Working Group. N Eng
J Med. 1993; 329(27): 1977-81.

10. Loeve F, Boer R, Zauber AG. National polyp study data evidence for regression of Adenomas. Int J Cancer. 2004; 111(4): 633.

11. Rasul KI, Awidi AS, Mubarak AA, al Hamsi UM. Study of colorectal cancer in Qatar. Saudi Med J. 2001; 22(8): 705-7.

12. Sing Y, Vaidya $P$, Hemandas AK. Colorectal carcinoma in Nepalese young adults, presentation and outcome. Gan to kagaku Ryoho. 2002; 29: 223-9.

13. Al Jaberi TM, Yagha RJ, EL Heis HA. Colorectal cancer in young patients under 40 years of Age; comparison with old patients in a well defined Jordanian population. Saudi Med J. 2003; 24(8): 8714.

14. EL Henna WY, MM Mousa ME, el saeidy MK. Rectal ca in Egyptian patients less than 40 years of age. Int Surg. 2003; 88(3) 137-44.

15. Chiang JM, Chen MC, Chang chien CR, Chen JS. Favorable influence of age on tumour characteristics of sporadic colorectal adeno-carcinoma patients 30 years of age or younger may be a distinct patient group. Dis Colon Rectum. 2003; 46 (7): 904-10.

16. Turkiwicz D, Miller B, Schache D, Cohen J. Young patients with colorectal cancer: how do they fare? ANZ J Surg. 2001; 71(12): 707-10.

17. Lin JI, Wang WS, Yen CC, Liu JH, Yang $\mathrm{MH}$. Outcome of colorectal carcinoma in patients under 40 years of age. J Gastroenterol Hepatol. 2005; 20(6) 900-5.

18. Yiu HY, Whitemore AS, Shibata A. Increasing colorectal cancer incidence rates in Japan. Int $\mathrm{J}$ Cancer. 2004; 109(5): 777-81-9.

19. Kan $\mathrm{MH}$, Eu KW, Barban CP. Colorectal cancer in the young: a 12 years review of patients 30 years or less. Colorectal Dis. 2004; 6(3): 191-4.

20. O'Connell JB, Maggard MA, Liu JH, Etzioni DA, Livingston $\mathrm{EH}$, Ko CY. Do young colon cancer patients have worst outcome? World J Surg. 2004; 28(6):558-62. 